\title{
Balai Kesehatan Jiwa dengan Pendekatan Healing ENVIRONMENT DI SURAKARTA
}

\author{
Deva Bagus Zhafran, Hardiyati, Leny Pramesti \\ Program Studi Arsitektur \\ Fakultas Teknik \\ Universitas Sebelas Maret Surakarta \\ Email:devazhafran@gmail.com
}

\begin{abstract}
Mental health is projected to be one of issues that would be a problem among people's live in the future. This issue is caused by a lack of knowledge and insight into the mental health community, as well as the negative stigma attached to people's perceptions of mental illness and the sufferers. The negative stigma hamper government and community efforts in creating mental health in the community. Stigma obstruct the recovery process of mental disorders that can happen to any human being and for the sufferers will be difficult to live in the midst of the general public. "balai kesehatan jiwa" that is designed aiming at providing a forum for people with mental disorders transition before returning to the life of society, as well as to create containers mental health services closer to the people so that the people who sought mental health can be achieved more efficiently. the concept of environment's design is applied using a basic principle as the basis of healing environmental considerations whole aspects both component architecture and components forming other neighborhoods that are conducive and supportive user's mental health. This building is planned by the location, building appearance, structure, landscaping and utilities on the building considering the stimulants wich is received by the users from the building components.
\end{abstract}

Keywords: Negative Stigma, Mental Health Centre, Containers Transition, Healing Environment

\section{PENDAHULUAN}

Stigma negatif tentang gangguan jiwa merupakan permasalahan utama yang melatarbelakangi ide perencanaan dan perancangan balai kesehatan jiwa tersebut. Stigma negatif yang sudah melekat pada persepsi setiap orang memiliki dampak negatif bagi orang lain bahkan dirinya sendiri. Stigma negatif bahwa gangguan jiwa akan menyebabkan orang bertindak kekerasan, tidak dapat disembuhkan dan menjadi aib bagi seseorang telah menjadi masalah serius ditengah-tengah masyarakat. Adanya stigma negatif ini diperburuk dengan perilaku dari masyarakat yang seolah-olah membenarkan stigma tersebut. Akibatnya, banyak kasus pemasungan, stres, halusinasi, dan kasus kesehatan jiwa lainnya yang semakin parah akibat penanganan yang terlambat atau kurang tepat karena kurangnya pengetahuan dan wawasan masyarakat. Adanya stigma ini mempersulit hubungan antara masyarakat umum dengan penderita gangguan jiwa yang juga menginginkan kehidupannya kembali, sehingga masalah dari stigma negatif tersebut menyebar menjadi permasalahan banyaknya gelandangan psikosis di kota-kota di Indonesia (depkes.go.id).

Balai kesehatan jiwa yang direncanakan bertujuan untuk memberikan wadah transisi bagi penderita gangguan jiwa sebelum dapat benar-benar kembali ke tengah-tengah masyarakat. Para penderita ini diberdayakan dan diberi bekal untuk hidup di masyarakat sebagai mantan penderita gangguan jiwa. Selain itu, balai kesehatan jiwa ini juga menyediakan pelayanan kesehatan jiwa bagi masyarakat umum. Sejauh ini, masyarakat umum mengetahui pelayanan kesehatan jiwa hanya pada rumah sakit jiwa, dan tempat-tempat praktek psikiatri yang tidak banyak diketahui oleh masyarakat itu sendiri. Gangguan jiwa dapat menyerang siapa saja, karena pada dasarnya setiap manusia memiliki perbedaan faktor psikologis dimana pada titik tertentu 
dapat dikatakan mengalami gangguan atau abnormal (Eko Prabowo, 2014). Menanggapi masalah-masalah tersebut, balai kesehatan jiwa yang dirancang ini berupaya untuk mendekatkan dan memberi wadah bagi masyarakat umum dan penderita gangguan jiwa untuk mendapatkan pelayanan kesehatan jiwa serta berinteraksi dengan tujuan pengurangan dan menghilangkan stigma negatif yang melekat diantara kedua belah pihak.

Healing Environmentdigunakan sebagai metode pendekatan pada perancangan balai kesehatan jiwa ini. Prinsip-prinsip pada Healing Environmentdinilai cocok sebagai kriteria keputusan desain yang diambil pada perancangan lingkungan yang direncanakan. Lingkungan menjadi salah satu faktor yang sangat berperan dalam proses penyembuhan dan penciptaan kesehatan jiwa masyarakat. Desain pada lingkungan di sekitar sangat mempengaruhi tingkat kesembuhan pengguna. Pola Perilaku penggunajuga dipengaruhi oleh rangsangan-rangsangan diterima dari lingkungan (Joyce Marcella Laurens, 2004). Beberapa kasus telah membuktikan bahwa pasien gangguan jiwa kembali kambuh setelah dipulangkan kerumahnya karena kondisi lingkungan rumahnya dianggap tidak kondusif dan justru memberikan rangsangan buruk. Untuk mendukung upaya penciptaan kesehatan jiwa dan kesejahteraan hidup masyarakat, Healing Environmentditerapkan guna menciptakan lingkungan yang kondusif dan supportive bagi kesehatan jiwa manusia.

\section{METODE}

Pada dasarnya, Healing Environmentmenitikberatkan pada metode perancangan seluruh aspek pada komponen arsitektur terutama komponen-komponen pembentuk lingkungan. Selain komponen pembentuk lingkungan ini yang nantinya akan berinteraksi langsung dengan pengguna melalui panca indera. Komponen-komponen tersebut antara lain adalah:

1. Peruangan

2. Lokasi

3. Komponen pembentuk lingkungan:
a. Warna.
b. View.
c. Bentuk.
d. Tekstur.
e. Pencahayaan.
f. Suara.
g. Termal.
h. Aroma.

Komponen-komponen

pembentuk lingkungan tersebut memiliki berbagai jenis dan macamnya. Pemilihan jenis dari berbagai macam komponen-komponen desain tersebut didasarkan atas kriteria yang digunakan sesuai dengan prinsip Healing Environmentuntuk perancangan wadah pelayanan kesehatan jiwa.

Prinsip Healing Environmentyang digunakan mengalami pengembangan yaitu merujuk pada prinsip-prinsip Healing Environmentuntuk fasilitas kesehatan jiwa. Pengembangan khusus ini bertujuan untuk mendapatkan kriteria perancangan yang lebih spesifik dan sesuai dalam perancangan lingkungan yang memulihkan dan menciptakan suatu kesehatan khususnya kesehatan mental atau jiwa penggunanya. (Ralene van der Walt and Ida Breed, 2012). Prinsip-prinsip tersebut antara lain adalah:

1. Stimulant (rangsangan)

2. Coherence (kesinambungan)

3. Affordance (keberhasilan)

4. Independence(kebebasan/keleluasaan)

5. Consciousness (kesadaran)

6. Purpose (kujuan)

7. Physical Activities (kegiatan kisik)

8. Restorative (pemulihan)

Prinsip-prinsip tersebut digunakan dan diterapkan dalam proses analisis setiap komponen perancangan balai kesehatan jiwa yang direncanakan. Arsitektur memiliki peran penting dalam kesehatan jiwa manusia, karena arsitektur merupakan ilmu perancangan lingkungan yang menjadi wadah bagi manusia menciptakan kesehatan tersebut (Gary W. Evans And Janetta Mitchell Mccoy, 1998).

\section{ANALISIS}

\subsection{Analisis Peruangan}

Kebutuhan ruang pada balai kesehatan jiwa yang dirancang didapatkan dari hasil pengamatan preseden dan kriteria perancangan dari prinsip-prinsip Healing Environmentyang digunakan sebagai pendekatan (Tabel 1). Kebutuhan ruang tersebut diolah dengan mempertimbangkan pola hubungan ruang untuk memberikan kemudahan dan kenyamanan pengguna dalam berkegiatan.

Tabel 1. Analisis Kebutuhan Ruang.

\begin{tabular}{|l|l|}
\hline Pelaku & Kebutuhan ruang \\
\hline Pengelola & $\begin{array}{l}\text { Ruang kerja } \\
\text { Ruang servis }\end{array}$ \\
\hline $\begin{array}{l}\text { Masyarakat } \\
\text { Umum }\end{array}$ & $\begin{array}{l}\text { UGD } \\
\text { Poli Kesehatan Umum }\end{array}$ \\
\hline
\end{tabular}




\begin{tabular}{|l|l|}
\hline & Poli Kesehatan Jiwa \\
& Perpustakaan \\
& Ruang Pelatihan Petugas \\
& Kesehatan Jiwa Pelatihan \\
& Ruang Penyuluhan \\
& Pengembangan Diri \\
& Ruang dan \\
& Kesehatan Jiwa \\
& Keluarga penderita \\
& Ruang Serbaguna \\
& Taman \\
\hline Orang Dengan & Taman \\
Gangguan & Ruang Serbaguna \\
Jiwa (ODGJ) & Ruang Keagamaan \\
& Ruang Kegiatan Binaan \\
& Ruang Kesehatan \\
& Ruang Keluarga \\
& Rumah Singgah \\
& Ruang Isolasi / Transisi \\
\hline
\end{tabular}

\subsection{Analisis Lokasi}

Lokasi mempengaruhi kualitas suatu lingkungan pada kawasan. Pemilihan lokasi yang tepat berhubungan dengan kenyamanan pengguna untuk mencapai kesehatan jiwa yang diinginkan.

\subsubsection{Tujuan}

Tapak yang mendukung kenyamanan dan keamanan kegiatan pada balai kesehatan jiwa sesuai dengan prinsip Healing Environmentyang diterapkan.

\subsubsection{Dasar pertimbangan}

Pertimbangan pemilihan lokasi berdasarkan prinsip Healing Environmentdan hasil pengamatan langsung terhadap pengguna yaitu penderita gangguan jiwa, yaitu:

a. Lokasi mampu menciptakan kondisi lingkungan yang cukup tenang.

b. Berhubungan dengan lingkungan kehidupan masyarakat.

c. Akses yang cukup mudah ke rumah sakit rujukan (RSJ / RSU).

d. Memiliki akses yang mudah ke lokasilokasi penting.

e. Berada pada daerah dengan iklim dan cuaca yang mendukung untuk proses penyembuhan penderita gangguan jiwa.

f. Memiliki view atau pemandangan yang dapat dinikmati.

\subsection{Analisis Komponen Pembentuk}

\section{Lingkungan}

\subsubsection{Warna}

Komponen warna pada lingkungan dianalisis dengan menggunakan beberapa prinsip dalam pendekatan yaitu:

1. Stimulant (rangsangan).

2. Coherence (kesinambungan).

3. Consciousness (kesadaran).

4. Restorative (pemulihan).

Tabel 2. Analisis Warna

\begin{tabular}{|l|l|}
\hline \multicolumn{1}{|c|}{ Warna } & \multicolumn{1}{|c|}{ Keterangan } \\
\hline Warna cerah natural (putih) & Bersih \\
\hline $\begin{array}{l}\text { Warna cerah natural (abu- } \\
\text { abu muda) }\end{array}$ & $\begin{array}{l}\text { Bersih, alami, } \\
\text { ketenangan }\end{array}$ \\
\hline $\begin{array}{l}\text { Warna tanah (cokelat, abu- } \\
\text { abu tua, dan warna-warna } \\
\text { tanah lainnya) }\end{array}$ & Membumi \\
\hline Kuning & Optimis \\
\hline Oranye & Semangat \\
\hline Merah & Berani, tegas \\
\hline Merah muda & $\begin{array}{l}\text { Cinta, kasih } \\
\text { sayang }\end{array}$ \\
\hline Ungu & Meditasi \\
\hline Hijau & $\begin{array}{l}\text { Keseimbangan, } \\
\text { alami, segar }\end{array}$ \\
\hline Turquois & Menenangkan \\
\hline Biru & Tenang \\
\hline
\end{tabular}

Analisis warna bertujuan untuk mengetahui efek yang diberikan pada penggunaan warnawarna tertentu (Tabel 2).

\subsubsection{View}

Komponen view pada lingkungan dianalisis dengan menggunakan beberapa prinsip dalam pendekatan yaitu:

1. Stimulant (rangsangan).

2. Consciousness(kesadaran).

3. Restorative (pemulihan).

Analisisview pada tapak

Lingkungan yang dirancang di desain sedemikian rupa dengan memanfaatkan view buatan dan view eksisting pada tapak (Gambar $1)$. 


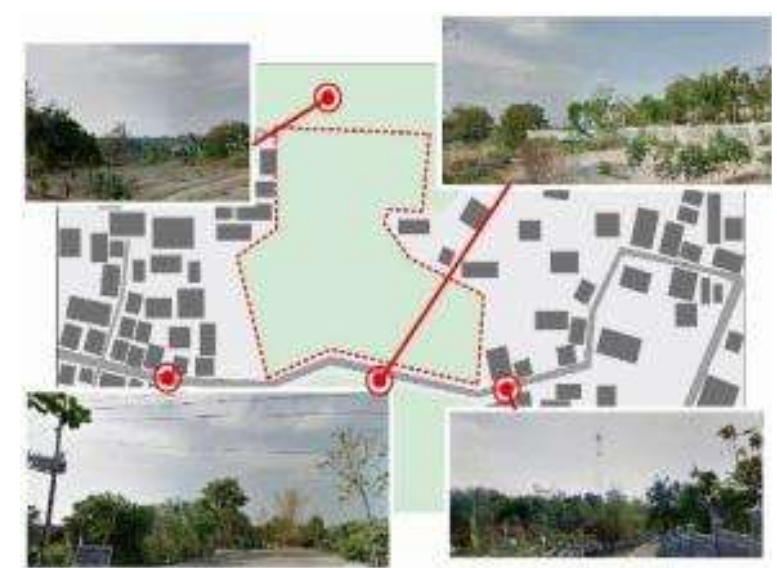

Gambar 1. AnalisisView Pada Tapak

\subsubsection{Bentuk}

Komponen bentuk pada lingkungan dianalisis dengan menggunakan beberapa prinsip dalam pendekatan yaitu:

1. Stimulant (rangsangan).

2. Coherence (kesinambungan).

3. Consciousness (kesadaran).

4. Restorative (pemulihan).

Proses pemilihan bentuk pada desain didasarkan pada hasil analisis dari beberapa bentuk geometris (Tabel 2).

Tabel 2 Analisis bentuk geometris.

\begin{tabular}{|c|c|}
\hline Bentuk & Analisis \\
\hline Persegi & $\begin{array}{ll}\text { 1. } & \text { Merupakan bentuk yang } \\
\text { paling efektif untuk suatu } \\
\text { ruangan. } \\
\text { 2. } \\
\text { Hubungan antar ruang } \\
\text { yang dibentuk komposisi } \\
\text { persegi cenderung kaku } \\
\text { dan memberikan kesan } \\
\text { jauh menurut aspek } \\
\text { sirkulasi. }\end{array}$ \\
\hline Segitiga & $\begin{array}{l}\text { 1. Komposisi segitiga } \\
\text { menciptakan hubungan } \\
\text { antar ruang dalam yang } \\
\text { dekat dan intim. } \\
\text { 2. } \begin{array}{l}\text { Memiliki sudut-sudut yang } \\
\text { runcing yang kurang baik } \\
\text { pada ruang. }\end{array} \\
\end{array}$ \\
\hline Lingkaran & $\begin{array}{l}\text { 1. Bentuk ruang dalam dari } \\
\text { bentuk lingkaran } \\
\text { cendurung kruang efektif } \\
\text { untuk perletakan perabot } \\
\text { yang digunakan oleh } \\
\text { pengguna di dalamnya. } \\
\text { 2. Bentuk lingkaran } \\
\text { memberikan kesan yang } \\
\text { luas dan lapang pada suatu } \\
\end{array}$ \\
\hline
\end{tabular}

ruang terutama ruang luar.

Analisa bentuk geometris tersebut bertujuan untuk mendapatkan kesimpulan dari sifat-sifat bentuk geometris yang akan di terapkan sebagai keputusan desain pada proses perancangan balai kesehatan jiwa.

1. Terpusat

Tata massa dimana adanya ruang pemersatu antar massa bangunan yang terdiri dari pusat yang dikelilingi massa sekunder.

2. Linier

Bersifat fleksibel dan tanggap terhadap kondisi tapak.

3. Grid

Merupakan tata massa pengulangan modul secara teratur.Penataan ini memberikan kesan kaku.

4. Cluster

Tata massa penggabungan dari ruang yang berlainan bentuk tapi tetap berhubungan dengan yang lain berdasarkan penempatan.

5. Radial

Tata massa perpaduan dari organisasi masa terpusat dan linear yang terdiri dari ruang pusat dengan beberapa organisasi linear berkembang membentuk jari.

\subsubsection{Tekstur}

Komponen tekstur pada lingkungan dianalisis dengan menggunakan beberapa prinsip dalam pendekatan yaitu:

1. Stimulant (rangsangan).

2. Purpose (tujuan).

Tabel 3. Analisis tekstur material.

\begin{tabular}{|c|c|c|c|}
\hline Bahan & Warna & Tekstur & Efek Psikologis \\
\hline Rumput & Hijau & Halus & Rileks/santai \\
\hline Tanah & Merah & Halus & $\begin{array}{c}\text { Membangkitkan } \\
\text { Semangat }\end{array}$ \\
\hline $\begin{array}{c}\text { Batu } \\
\text { Kerikil }\end{array}$ & $\begin{array}{c}\text { Abu- } \\
\text { abu }\end{array}$ & Kasar & Ketenangan \\
\hline $\begin{array}{c}\text { Tanah } \\
\text { Liat } \\
\text { Berpasir }\end{array}$ & $\begin{array}{c}\text { Abu- } \\
\text { abu }\end{array}$ & Halus & Ketenangan \\
\hline $\begin{array}{c}\text { Batu } \\
\text { Bata }\end{array}$ & Merah & Halus & $\begin{array}{c}\text { Membangkitkan } \\
\text { Semangat }\end{array}$ \\
\hline $\begin{array}{c}\text { Batu } \\
\text { Alam }\end{array}$ & $\begin{array}{c}\text { Putih, } \\
\text { Abu- } \\
\text { abu }\end{array}$ & Kasar & Ketenangan \\
\hline
\end{tabular}

(Ralene van der Walt dan Ida Breed, 2012) 
Pada dasarnya, tekstur dibedakan mejadi dua jenis, yaitu tekstur kasar dan halus. Penggunaan tekstur pada kawasan diutamakan tekstur yang berasal dari alam (Tabel 3), untuk menciptakan suasana yang lebih alami pada lingkungan.

1. Penggunaan tekstur kasar pegangan oleh pengguna seperti railing, dinding.
a. Objek yang difungsikan sebagai
b. Path jalan pada taman untuk menciptakan kesadaran ruang jalan dan keamanan pengguna.

2. Penggunaan tesktur halus
a. Penggunaan material dengan tekstur halus pada objek-objek yang digunakan sebagai tempat beristirahat.
b. Penggunaan tekstur halus pada suatu ruang membuat psikologispengguna lebih tenang.

\subsubsection{Pencahayaan}

Analisis berdasarkan pendekatan

1. Independence (kebebasan/keleluasaan).

2. Consciousness (kesadaran).

3. Purpose (tujuan).

Sumber cahaya ada dua yaitu alami (cahaya matahari) dan buatan (lampu). Pencahayaan alami dapat diperoleh melalui bukaan pada dinding (jendela) maupun pada langit-langit (skylight). Manfaat pencahayaan alami khususnya pada kondisi psikis seseorang adalah mengurangi kecemasan psikis (psychological fatigue) serta mendorong emosi positif seseorang.

\subsubsection{Suara}

Suara merupakan unsur yang cukup banyak ada di lingkungan. Komponen suara pada lingkungan dianalisis dengan menggunakan beberapa prinsip dalam pendekatan yaitu:

1. Stimulant (rangsangan).

2. Restorative (pemulihan).

Suara pada lingkungan memberikan kemungkingan berbagai rangsangan buruk dan baik yang memberikan rangsangan buruk antara lain bersumber dari:

1. Kegiatan manusia.

2. Kegiatan kendaraan.

3. Kegaduhan Orang Dengan Gangguan Jiwa

(ODGJ) lain.

Suara dapat memberi rangsangan baik yang bersumber dari:

1. Suara-suara alam.

2. Musik dengan irama pelan.
Hasil analisis suara yang didapatkan bertujuan untuk memberikan respon desain khusus pada lingkungan untuk mengurangi rangsangan buruk yang dapat diterima oleh pengguna pada lingkungan Balai Kesehatan Jiwa.

\subsubsection{Termal}

Komponen termal pada lingkungan dianalisis dengan menggunakan beberapa prinsip dalam pendekatan yaitu:

1. Independence (keleluasaan).

2. Restorative (pemulihan).

Keleluasaan pengguna dalam mengendalikan termal di analisis dari 2 komponen klimatologi yaitu matahari dan angin.

1. Pengendalian termal matahari.

2. Pengendalian termal angin.

3. Pengendalian termal dengan alat.

Penciptaaan desain lingkungan yang memulihkan, maka dari hasil analisis didapatkan beberapa rekayasa desain yang digunakan untuk mengatasi komponen termal pada lingkungan, yaitu:

1. Perencanaan arah orientasi bangunan.

2. Perletakan vegetasi pada lingkungan.

3. Perletakan ruang-ruang yang mempengaruhi termal lingkungan.

4. Penggunaan tritisan pada bukaan.

5. Penggunaan atap miring dengan ruang untuk sirkulasi udara dengan kombinasi roof garden.

\subsubsection{Aroma}

Komponen aroma pada lingkungan dianalisis dengan menggunakan salah satu prinsip dalam pendekatan yaiturestorative (pemulihan).

Beberapa penelitian telah membuktikan bahwa aroma bunga dan buah dapat memperlambat pernafasan, mengurangi tekanan darah dan denyut jantung, serta membuat otot rileks. Wewangian juga dapat mengurangi rasa sakit dengan merangsang kelenjar tubuh untuk mengeluarkan endorphine, salah satu hormon pereda rasa sakit paling kuat yang dimiliki tubuh.

Berikut ini adalah macam-macam tanaman yang dapat digunakan sebagai aromaterapi:

1. Lavender: biasanya dipakai sebagai antiseptik serta menyembuhkan luka kecil dan luka bakar. Selain itu digunakan untuk relaksasi dan pereda sakit kepala. 
2. Mawar: aroma yang dikeluarkan berkhasiat untuk meningkatkan kegiatan memori otak serta semangat kerja.

3. Cendana: memiliki efek stimulasi sekaligus relaksasi sehingga baik untuk meredam ketegangan, ketakutan, maupun rasa cemas.

4. Melati: aroma yang dikeluarkan mampu meningkatkan kegiatan gelombang beta di otak sehingga kemampuan berpikir lebih optimal, positif, meningkatkan kejernihan pikiran, dan ketenangan jiwa.

5. Kenanga: aroma yang dikeluarkan akan mempengaruhi dan mengatur aliran kelenjar adrenalin dalam sistem syaraf sehingga menimbulkan perasaan senang dan tenang.

6. Rosemary: aromanya dapat menyegarkan tubuh dan pikiran serta mengembalikan rasa percaya diri.

7. Geranium: sering dipakai untuk mengurangi ketegangan syaraf sebagai afrodisiak karena aromanya dapat meregangkan produksi hormon.

Hasil analisis komponen-komponen pembentuk lingkungan tersebut akan diterapkan sesuai kebutuhan pada desain Balai Kesehatan Jiwa yang di rancang dan diharapkan mampu memberikan rangsangan positif untuk terciptanya kesehatan jasmani maupunpsikologis penggunanya.

\section{KESIMPULAN (KONSEP DESAIN)}

Konsep perancangan balai kesehatan jsiwa mengacu pada prinsip Healing Environment. Prinsip-prinsip tersebut digunakan sebagai landasan kriteria pemilihan keputusan desain komponen-komponen arsitektur pada proses perencanaan dan perancangan yang menitikberatkan pada peruangan, lokasi, dan komponen pembentuk lingkungan.

Nama proyek : Balai Kesehatan Jiwa.

Lokasi : Jl Sumbing raya, Jebres, Mojosongo.

Luas lahan

Luas bangunan $: 17.009,178 \mathrm{~m}^{2}$

Jenis kegiatan : Pelayanan kesehatan jiwa masyarakat dan pemberdayaan Orang Dengan Gangguan Jiwa (ODGJ).

Hasil Desain:

Balai kesehatan jiwa yang dirancang menerapkan prinsip-prinsip pada Healing Environmentterutama pada konsep peruangan, konsep lokasi, dan konsep perancangan komponen-komponen pembentuk lingkungan. Perancangan ruang dan lokasi bertujuan untuk menciptakan suasana yang kondusif dan supportive untuk kenyamanan, keamanan dan keselamatan pengguna dimana banyak diantaranya adalah Orang Dengan Gangguan Jiwa (ODGJ).

Peruangan dan lokasi yang dipilih ditentukan berdasarkan aspek kenyamanan, keamanan dan kemudahan bagi pengguna untuk berkegiatan pada kawasan Balai Kesehatan Jiwa yang dirancang. Komponen-komponen pembentuk ruang yang di rancang meliputi warna, bentuk, view, tekstur, pencahayaan, suara, aroma, dan termal dengan menerapkan prinsip-prinsip Healing Environmentsebagai kriteria perancangan balai kesehatan jiwa. Secara keseluruhan, komponen-komponen arsitektur lainnya seperti struktur, utilitas, dan material juga menggunakan prinsip-prinsip Healing Environmentsebagai dasar analisis. Seluruh komponen arsitektur yang diolah menjadi konsep perancangan didesain dengan tujuan menciptakan lingkungan yang memberi rangsangan baik secara psikologis dan jasmani kepada pengguna.

Keputusan desain yang digunakan pada kawasan mengacu pada hasil analisis komponen-komponen pembentuk lingkungan dengan menggunakan prinsipHealing Environment.Keputusan desain tersebut terlihat pada desain perancangan tapak (Gambar 2), Pengolahan lansekap (Gambar 3 dan Gambar 4), tampilan luar bangunan (Gamabr 5 dan 6), dan tampilan dalam bangunan (Gambar 7 dan 8). Keputusan desain tersebut dipilih sebagai penerapan prinsip pendekatan Healing Environment yang bertujuan untuk menciptakan suatu kesehatan jasmani maupun psikologi pengguna yang berkegiatan pada lingkungan tersebut.

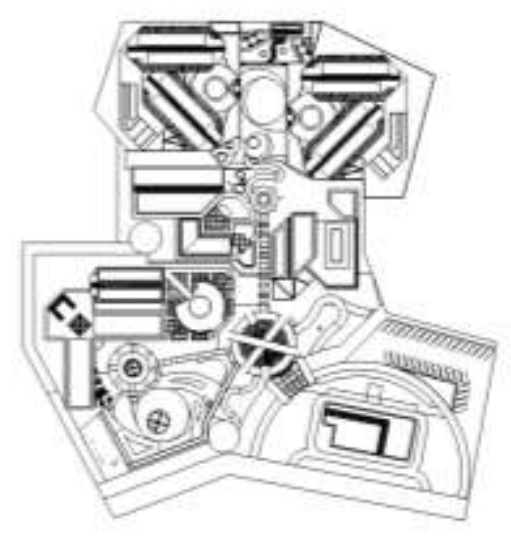

Gambar 2. Susunan Tata Massa Kawasan 


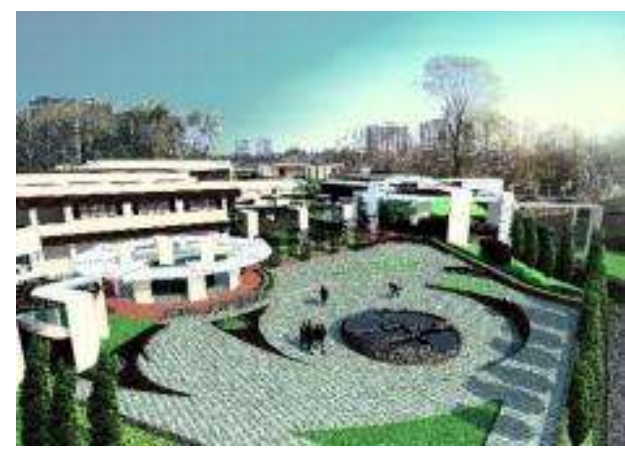

Gambar 3. Penggunaan Elemen-Elemen Alam pada Tapak dan Bangunan

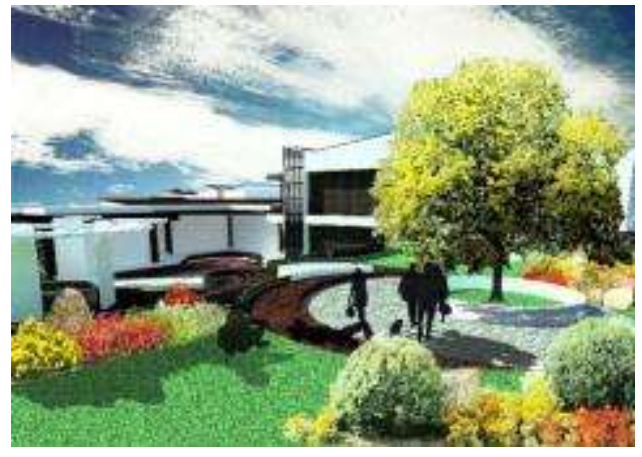

Gambar 4. Konsep Komponen Bau dan Warna pada Taman

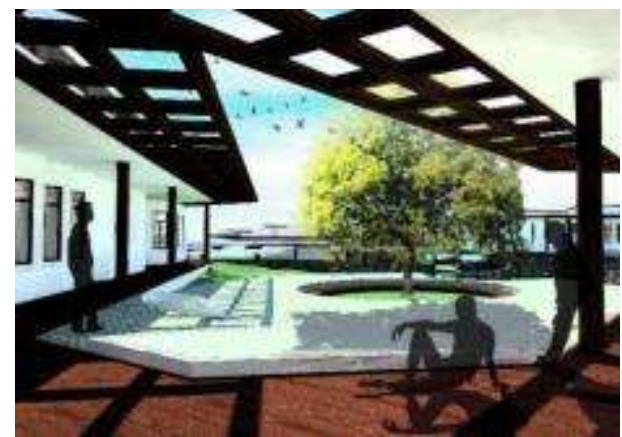

Gambar 5. Penerapan Prinsip Healing Environment yaitu Pemulihan pada Bangunan

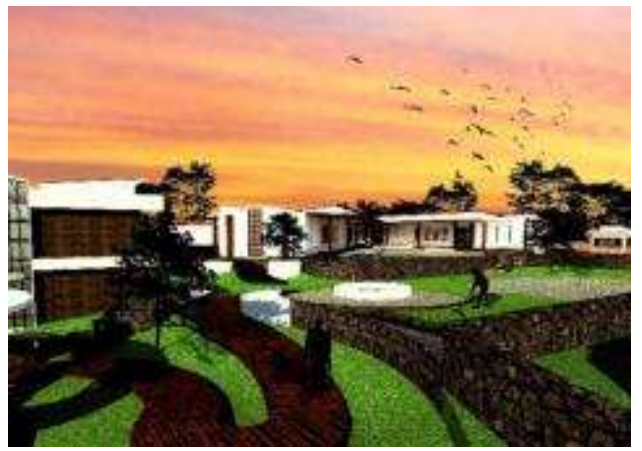

Gambar 6. Penerapan Konsep Pencahayaan pada Bangunan

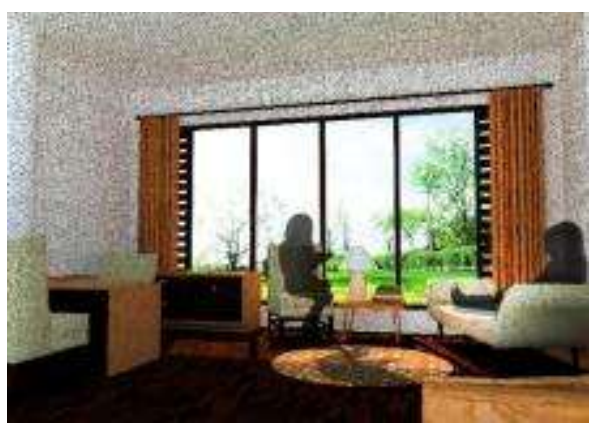

Gambar 7. Penerapan Konsep View pada Interior Ruangan

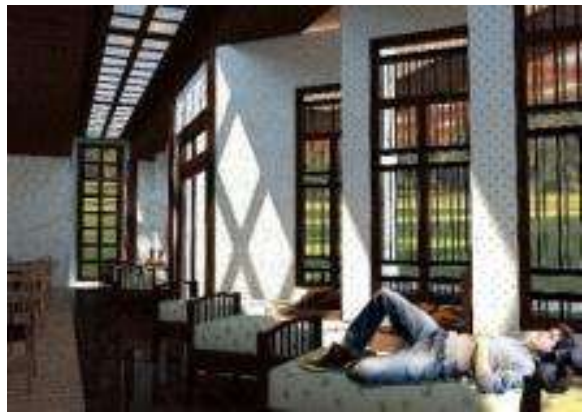

Gambar 8. Konsep Perancangan Ruang Inap Orang Dengan Gangguan Jiwa (ODGJ)

\section{REFERENSI}

Gary W. Evans And Janetta Mitchell Mccoy, 1998. "When Buildings Don't Work: The Role Of Architecture In Human Health". Journal of Environmental Psychology. Vol 18, no 85-94. http://citeseerx.ist.psu.edu, 15 agustus 2016

Laurens, Joyce Marcella. 2004 Arsitektur dan Perilaku Manusia. Jakarta; PT. Grasindo

Prabowo, Eko. 2014.Buku ajar Keperawatan Jiwa.Yogyakarta Nuha Medika.

Ralene van der Walt and Ida Breed, 2012. "The mindful landscape: a healing outdoor experience for Weskoppies psychiatric hospital". Vol 27, no. 2. http://hdl.handle.net/2263/21190, 30 juli 2016

http://www.depkes.go.id diakses pada 18.03.2016 (23.30)

http://www.creativecolormetabolismehemes.co $\mathrm{m} /$ resources/free-color-

metabolismehemes/earth-tone-colormetabolismeheme.shtml diakses pada 10.08.2016 (20.55) 